\title{
The formation of highly qualified personnel is the goal of the educational process
}

\section{Zarifa NURMAMATOVA ${ }^{1}$}

Navoi State Pedagogical Institute

\begin{tabular}{l} 
ARTICLE INFO \\
\hline Article history: \\
Received May 2021 \\
Received in revised form \\
20 May 2021 \\
Accepted 15 June 2021 \\
Available online \\
15 July 2021 \\
\hline Keywords: \\
education, \\
upbringing, \\
spirituality, \\
the concept of a perfect \\
person, \\
philosophical, \\
legal, \\
artistic, \\
moral, \\
religious imagination and \\
modern education.
\end{tabular}

ABSTRACT

In this article, an important issue in the formation of the younger generation and highly qualified personnel, that is, the development of Science, the attitude of young people to the national heritage and the importance of the issue of education resulting from the current modern demand.

2181-1415/C 2021 in Science LLC.

This is an open access article under the Attribution 4.0 International (CC BY 4.0) license (https://creativecommons.org/licenses/by/4.0/deed.ru)

\section{Юксак малакали кадрларни шакллантириш-таълим тарбия жараёнининг мақсади}

\author{
Калит суцзлар: \\ таълим, \\ тарбия, \\ маънавият, \\ комил инсон, \\ фалсафий, \\ хукуқий, \\ бадиий, \\ ахлоқий, \\ диний тасаввурлар ва \\ замонавий таълим-тарбия \\ концепцияси.
}

АННОТАЦИЯ

Мазкур мақолада ёш авлодни ва юксак малакали кадрларни шакллантиришдаги мухим масала, яъни илмфан ривожи, ёшларнинг миллий меросга бўлган муносабати ва хозирги замонавий талабдан келиб чиққан таълимтарбия масаласининг мухимлиги кўриб чиқилган.

\footnotetext{
${ }^{1}$ English Language lecturer, Navoi State Pedagogical Institute, Navoi, Uzbekistan.
} 


\section{Цель образовательного процесса - формирование высококвалифицированных кадров}

\author{
Ключевые слова: \\ образование, \\ воспитание, \\ духовность, \\ совершенный человек, \\ философские, \\ правовые, \\ художественные, \\ нравственные, \\ религиозные идеи и \\ современные \\ образовательные \\ концепции.
}

АННОТАЦИЯ

\begin{tabular}{l}
\hline В статье рассматриваются важные вопросы \\
формировании подрастающего \\
высококвалифицированных кадров, а именно развитие \\
науки, отношение молодежи к национальному наследию и \\
важность образования, вытекающая из современных \\
требований.
\end{tabular}

\section{INTRODUCTION}

Our homeland is the land of great scientists-fuzalos and thinkers. Our great thinker grandfathers, such as Imam Buhari, Burhoniddin Marginaniy, Isa Hakim at-Termiziy, Mahmud AZ-Zamahshari, Muhammad Qaffol Shoshiy, Bahouddin Naqshband, Hoja Ahror Valiy, Muhammad Al-Horezmi, Abu Rayhon Beruni, Abu Ali Ibn Sina, Mirzo Ulugbek, Alisher Navoi made a significant contribution to the development of world civilization.

President of the Republic of Uzbekistan Shavkat Mirziyoyev noted that "the education of the younger generation has become important and important in all times. But in the XXI century in which we live, this issue is really becoming a matter of life-mammoth... "The more perfect the upbringing, the happier the people live", says the wise. And in order for the upbringing to be perfect, it is absolutely impossible to allow the appearance of emptiness in this matter [1].

Attention to education-attention to the future. The potential of any country is determined by the awareness of young people, the assimilation of modern knowledge, in a word intellectual capacity higher.

\section{THE MAIN FINDINGS AND RESULTS}

Today, at a time when science, technical achievements have become the geographical and strategic potential of the state, and globalism covers the whole world, the state of human geography is the most important factor. On the one hand, the modern high development is fully realized due to the acceleration of production and realization of creative work, on the other hand, the organization of a strong ideological immunity against the threat of various foreign ideas and ideologies, the expression of the vital opportunities of our national mentality as a competent and mature specialist of young people. The basis of the control of the education and training system is the people, the nation has been raising and enriching their knowledge for years. Because the acquisition of knowledge is the basis of the requirements laid down in the system of thoughts, such as "look for knowledge from the cradle to the grave", as noted in Hadis.

The integration of these qualities into the minds of the modern younger generation is one of the most pressing problems, which requires a complex, multifaceted and long- 
term, pedagogical and psychological, coaching groundbreaking. The successful solution of these problems is entrusted to both the educator and the educator separately.

The educational process is an extremely complex sphere. The behavior, manners, attitude to the profession, loyalty to the national traditions and hormones of enlightenment, faith and pure conscience of the student, which he embodied throughout his life, allow him to become a Educator.

President of the Republic of Uzbekistan Shavkat Mirziyoyev, in his congratulatory message to teachers and mentors of Uzbekistan on September 31, 2017, stated that "we are thinking about the solution of complex and important issues that are facing us today, which are changing rapidly, we are once again convinced that their solution is connected with education, formation of the worldview of young people on.

The enthusiasm, enthusiasm, consistency, and aspiration of young people to Great Goals are all dependent on their wealth, content and level of confidence in the future of their educated and spiritual world. Morally, a poor person can never get knowledge with inspiration and overwork, he cannot work, he cannot get out of the whirlpool of everyday life, he cannot see the prospect. Educated individuals, these are our historical roots. Since man wants his knowledge and level to be mature, he must study the history of his people, the philosophical, legal, scientific, artistic, moral, religious and other reflections of this people, their originality. On this basis, a new generation forms a new, fully rich, spiritual world of the profession of a hermaphrodite.

The concept of modern education, which appeared in the years of the future of our new independent state, envisages on the one hand comprehensive and harmonic reproduction of the individual, on the other hand, full-fledged, physical development and provision of mental trigger health, starting from the first step that made it in the conditions of the family in life.

Man differs from other beings by the fact that he has consciousness, knowledge, intelligence, the ability to feel and understand the universe, spiritual qualities. In secular thinking, man is valued as an invaluable asset in terms of his abilities, intellectual potential and creativity. And in the philosophy of mysticism, it has its own definition. In particular, in the Quran it is said that "we have made you Mukarram". In our view, the same perfection is directly related to the perception and feeling of the mind, which is not given to any other creature except a person. Only a person was given the opportunity to think, react, understand the universe, understand the meaning of life and enrich it. In our view, knowledge, mind-wisdom are determined by the same aspects. If young people are able to manage their emotions and passions, if it is driven by reason of good will, then the above situation will lead to social progress and prosperity".

In the years of independence of our country, education, upbringing of a person from spiritual standpoint, the realization of the idea of national awakening has become one of the greatest tasks of our state to bring the new generation to adulthood.

It is known that the spiritual wealth of a person, in particular a teacher, is assessed by his worldview, the ability to think deeply, the ability to correctly react to events in a timely manner. "The origin of all vices is ignorance", was the great Greek philosopher Socrates. Therefore, we are all responsible for the high level of knowledge and thinking of our youth.

If the teacher knows his science perfectly, he will be able to convey it to students in a simple language. During the course, teachers teaching at the university should be in solidarity with the policy of the same state, the economy, the rules of legal law, underground, terrestrial wealth, environmental conditions, the army of the same society, 
cooperation with distant countries, the Times. To do this, it is necessary to regularly get acquainted with the news of the mass media.

During the passage of the lesson, the following events can be used in the passage of educational lessons. "Greet each other so that in the middle you will wake up in love". "Believers have six rights to each other: to say hello, to respond to sneezes, to see if they are sick, to be blackened at the funeral when they die".

The above-mentioned advice says that the inner image of the teacher is beautiful with the purity of his faith and conscience. He is able to love the student because of this beauty and educate him as his own child, breathe with the student's heart.

Man is essentially a creature doomed to self-perfection, self-development, in other words man lives 101 years, 103 years needs upbringing. Perfection, maturity is worthy only of high spirituality inherent in man, high status is worthy only of morality. Spirituality is the vulture of human life. It is one of the most important factors that determines the dignity of a person in all conditions, his dignity, reputation among the public.

Spirituality is the wing of the human hand. The betrothal base of his free and free will, his strength in conquering high peaks.

Spirituality is the power that saves a person from superstition, ignorance. Through the spiritual stability of individual, individual people, a spiritual image of a holistic society is formed. In a word, spirituality is the indomitable power, the incomparable power that drives society to action through a mature person in all respects.

Perfection, maturity, spiritual and spiritual perfection should be harmoniously combined with the fact that all good deeds and good deeds are yellowing.

The basis of education is education. After admission to the university, changes in their manners and behavior begin to appear, which we have seen from many years of experience.

At the age of 18-19, when the student reaches physical perfection, he begins to put himself in it a building, striving to look at everything in life independently, he manages his material income himself. But since life experience is left behind by physical perfection, the daily routine and influence of the mother and father will be of great importance in this period. In such a period, when young people are excluded from the influence of upbringing, both the right path and serious thinking and reasoning remain more important than ever before. At this time, we have learned and promoted the pedagogical views of some coaches. But we completely ignored the folk pedagogy, the unfinished forms and methods of education in books, which went back thousands of years with a stroke. The genius of wisdom is the people the wise are the children of this people.

Today, our lives with great ideas, Great Goals, noble intentions are known to the whole world. Each of us, in a hurry, without fuss, deeply studying those ideas and acting in the right way in our minds and abilities, the way of all selfish, contrary to conscience, faith is blocked. For this, it is necessary to be pure before conscience, no more. It is necessary to think more about our tomorrow, its meaning and appearance. What should we do so that the future doctors will form as mature people, that they will have a good education, that they will live as the continuation of our work!

Our main work today is to solve this problem. Even from the point of view of dialectics, if the education of students is accompanied by kindness, openness, striving for the formation of good qualities, assertiveness, some justifiable rigor, sufficient effect is achieved in moral education. It was tested in folk pedagogy.

"It is necessary to create the necessary environment and conditions for the rich history of our country among young people to widely promote its unique culture and 
national values, to convey the achievements of World Science and literature" [3]-said President Shavkat Mirziyoyev.

During the years of independence, many coverage works were started in Uzbekistan on the basis of the experiences of developed countries. In this place, it is necessary to note International Scientific and Current Research Conferences 15 March 2021 the great changes made in the reform of Education. The meaning and content of the reforms in the field of education and training is primarily aimed at raising the level of modern advanced technology standards, which are aimed at creating a wide path to the formation of talent and ability in young people, as well as providing a wide path to the level of teaching. The results of the work in this regard remained unnoticed.

Bringing up a thoughtful, educated, spiritually mature and harmonious generation to ensure a bright future of the new Uzbekistan is the main issues of Public Policy.

In his speech on "Historical heritage of medieval scholars and thinkers of the Middle East, its role and significance in the development of modern civilization" the First President of the Republic of Uzbekistan I.A Karimov called for the preservation, enrichment and reproduction of its historical, cultural and intellectual heritage. Any state and society that does not pay enough attention to educating the next generation in the spirit of national and universal values, develops in all respects, thinks independently, has its own views and approaches, does not aim to develop a civic position, is left out of history and development. We have a good idea of his conviction and we have a good idea of it" [4].

\section{CONCLUSION}

Therefore, the formation of the above-mentioned qualities, or in a word, helps to shed light on the essence of the issue, which needs to be paid more attention in shaping the national and spiritual image of today's youth.

\section{REFERENCES:}

1. Shavkat Mirziyoev. The consent of our people is the highest value given to our activities. Tashkent - "Uzbekistan" - 2018. - P. 448.

2. The news paper "People's Word". January 16, 2017.

3. Speech of the First President of the Republic of Uzbekistan Islam Karimov at the opening ceremony of the international conference "Historical heritage of medieval oriental scholars and thinkers, its role and significance in the development of modern civilization", a textbook for study in higher education. Toshkent -2014 . - P. 3.

4. "People's speech" May 16, 2014. International Scientific and Current Research Conferences 15 March 2021. 